ORCID: 0000-0002-4680-1466

\title{
В. В. Морозович
}

Аспірант кафедри фізики,

Черкаський національний університет імені Богдана Хмельницького, Черкаси, Україна, vladmorozua@gmail.com

ORCID: 0000-0001-8186-9354

\section{Я. Д. Король}

Кандидат фіз.-мат. наук, доцент,

директор навчально-наукового центру фізико-хімічних досліджень,

Черкаський національний університет імені Богдана Хмельницького, Черкаси, Україна, yaking@ukr.net

ORCID: 0000-0001-7015-1662

\section{Ю. О. Ляшенко}

Доктор фіз.-мат. наук, доцент, директор навчально-наукового інституту інформаційних та освітніх технологій, Черкаський національний університет імені Богдана Хмельницького, Черкаси, Україна, urico@ukr.net

\section{СТРУКТУРНИЙ СТАН ГАЛЬВАНООСАДЖЕНИХ ПРОШАРКІВ МІДІ}

Методами рентгенівського дифракиійного аналізу досліджено мікроструктуру прошарків міді, що отримані електроосадженням міді в стаціонарному, реверсному імпульсному та стохастичному режимах на мідні підкладки. Встановлено суттєвий вплив форми струму на текстуру осаджених прошарків міді. Було встановлено, що більш просторово однорідну структуру має осад, щзо отриманий в реверсному імпульсному режимі електроосадження. За постійного струму електроосадження формуються кристали з більш дефектною структурою. За допомогою аналізу уширення дифракиійних ліній визначено розміри областей когерентного розсіювання в прошарках, щзо отримані за різних режимів струму. Також встановлено, шчо після електролітичного осадження міді розмір зерен зменшується, порівняно з розмірами зерен в полікристалічній мідній підкладці.

Ключові слова: електроосадження, рентгеноструктурний аналіз, мідь, області когерентного розсіювання, дифрактограма.

\section{1. Ветуп}

Детальне дослідження структурованих матеріалів у порівнянні з полікристалічними аналогами [1] виявили їх технологічні відмінності, що характеризуються особливими термодинамічними та механічними властивостями та структурно-фазовим складом. Мідні контакти, як правило, отримують шляхом електролітичного осадження. Тому отримання прошарків міді 3 однорідною та бездефектною структурою $\epsilon$ важливою задачею в мікроелектроніці. Детальний опис теорії та технології стаціонарного режиму електроосадження приведено в науковій літературі, напр. [2]. Але електроосадження в стаціонарному режимі має ряд недоліків, зокрема нерівномірність товщини електроосаджених шарів. Застосування неоднорідних в часі режимів електроосадження [3-7], таких як імпульсний, коливальний, реверсивний (інверсний) режими електроосадження дозволяє уникнути недоліків стаціонарного режиму електроосадження.

* Статтю написано згідно з прикладною держбюджетною темою “Синтез наноструктурованих сплавів за осцилюючих напружень та їх застосування в новій технології з'єднання мікроелектронних компонентів” (номер державної реєстрації 0117U000577). 
Серія «Фізико-математичні науки», 2018

В роботах $[8,9]$ описано технологію застосування стохастичних режимів електроосадження та проведено порівняння їх застосування з іншими режимами. Встановлено особливості утворених текстур осаджених прошарків та досліджено вплив різних режимів осадження на наступну твердофазну реакцію мідь/олово.

Метою даної роботи є дослідження методами рентгенівського дифракційного аналізу структури електроосаджених в стаціонарному, реверсному імпульсному та стохастичному режимах прошарків міді, що отримані з застосуванням оригінального апаратно програмного комплексу (далі АПК) [10].

\section{2. Метод отримання прошарків електроосадженої в неоднорідних часових режимах міді}

Процес електроосадження проводився на підкладки міді розмірами $15 \times 10$ мм. Поверхні пластинок міді частково ізолювали таким чином, щоб забезпечити площу поверхні 1 $\mathrm{cm}^{2}$. Пластинки міді, що використовувались для електроосадження та побудови поляризаційної кривої, проходили етап шліфування та полірування із використанням шліфувальних кругів (Р180, Р1200, Р2400). Після полірування пластинки міді очищались в ультразвуковій ванні протягом 100 секунд. Після ультразвукової очистки пластинки міді піддавалися гомогенізуючому відпалу за температури $550{ }^{\circ} \mathrm{C}$ протягом 2 годин в атмосфері аргона. Перед електроосадженням зразки додатково очищали за допомогою електрохімічного травлення в електроліті, витримуючи відстань між анодом i катодом 5 см. Зразок підтравлювався протягом 10 хвилин за напруги $U=0,21$ В (густина струму становила $j=0,022 \mathrm{~A} / \mathrm{cm}^{2}$ ). Потім пластинки міді промивалися під струменем води. На очищені пластинки міді попередньо осаджували прошарок міді в стаціонарному режимі за густини струму $j=0,022 \mathrm{~A} / \mathrm{cm}^{2}$ протягом 10 хвилин. Для електролітичного осадження був використаний електроліт складу $0,36 \mathrm{M} \mathrm{CuSO}_{4} * \mathrm{H}_{2} \mathrm{O}+1,22 \mathrm{M} \mathrm{H}_{2} \mathrm{SO}_{4}$.

\section{1. Побудова поляризаційної кривої}

Відповідно до заданих умов електролізу (робоча площа зразків $\left(10^{*} 10\right.$ мм) та відстань між катодом і анодом 5 см) у гальванодинамічному режимі зі швидкістю $0,02 \mathrm{~B} / \mathrm{c}$ було побудовано поляризаційну криву. Побудована поляризаційна крива характеризує осадження міді на мідні пластинки за заданої концентрації та температури електроліту та приведена на Рис. 1.

На основі побудованої поляризаційної кривої визначено інтервали напруг, що відповідають активованому та дифузійному режиму електроосадження. Стаціонарні режими електроосадження проводилися за параметрами точок 1 та 2 на Рис. 1. Стохастичні режими електроосадження проводилися з застосуванням моделі генератора нелінійних коливань Чуа, коли нелінійні коливання напруги здійснювалися в околах точок 1 та 23 випадковими неперервними переходами між ними [8]. В цьому випадку мінімальне значення напруги становило 0.17 В, максимальне 0.56 В. Біля першої $(0.24$ В) та другої $(0.49$ В) стаціонарних точок максимальні відхилення амплітуди коливань напруги становили 0.07 В (див. Рис 2 a, в).

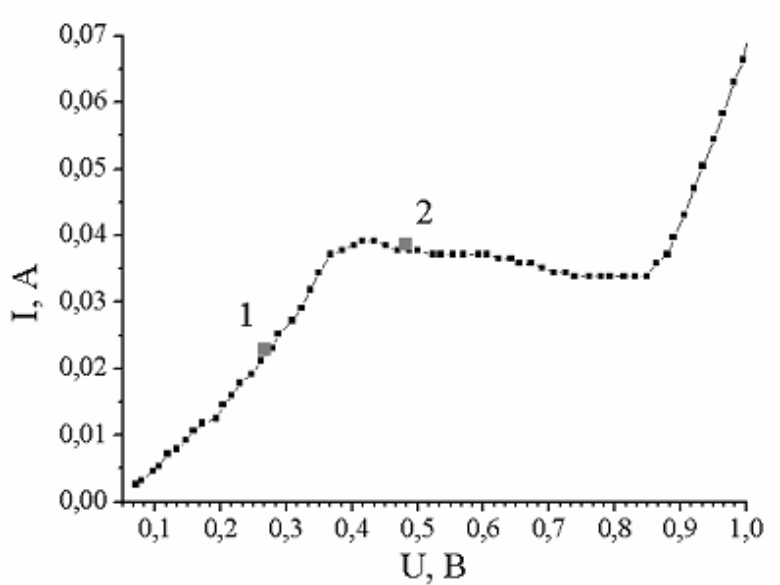

Рис. 1. Поляризаційна крива процесу електроосадження.

Fig. 1. Galvanodynamic polarization curve obtained at $\mathrm{Cu}$ electrodeposition. 
Контроль осадження здійснювався за допомогою фіксації сумарного заряду. В проведених експериментах було обрано значення сумарного заряду q $=86,54$ Кл. Iз врахуванням виходу за струмом (експериментально встановлено, що для даного електроліту вихід за струмом становив близько 55 \%) такий сумарний заряд відповідав масі осаду $\mathrm{m}=33$ мг, що в стаціонарних режимах електроосадження відповідає товщині приблизно до 100 мкм. Параметри електролітичного осадження в стохастичному, імпульсно реверсному та стаціонарному режимах електроосадження наведено в Таблиці 1.

Таблиця 1

Параметри електролітичного осадження

\begin{tabular}{|c|c|c|c|c|}
\hline № & Режим осадження & Напруга U, B & $\begin{array}{c}\text { Густина } \\
\text { струму j, } \\
\mathrm{A} / \mathrm{cm}^{2}\end{array}$ & Час осадження, хв \\
\hline Зразок 1 & Стаціонарний №1 & $0,24 \mathrm{~B}$ & 0,0113 & 110 \\
\hline Зразок 2 & Стаціонарний №2 & $0,499 \mathrm{~B}$ & 0,0431 & 47 \\
\hline Зразок 3 & $\begin{array}{c}\text { Повільний } \\
\text { стохастичний }(\mathrm{t}=1 \mathrm{c}) \\
\left(x_{0}=0,2,\right. \\
\alpha=7, \beta=10 \text { в } \\
\text { моделі Чуа [8]) }\end{array}$ & $\begin{array}{c}\mathrm{U}_{\min }=0,17 \mathrm{~B}, \\
\mathrm{U}_{\max }=0,56 \mathrm{~B}, \\
\mathrm{U}_{\mathrm{st}}=0,49 \mathrm{~B}, \\
\mathrm{U}_{\mathrm{st}}=0,24 \mathrm{~B}\end{array}$ & $\begin{array}{c}\mathrm{j}_{\min }= \\
0,0138, \\
\mathrm{j}_{\max }=0,031\end{array}$ & 55 \\
\hline Зразок 4 & $\begin{array}{c}\text { Швидкий } \\
\text { стохастичний }(\mathrm{t}=20 \\
\text { мс }) \\
\left(x_{0}=0,2,\right. \\
\alpha=7, \beta=10 \text { в } \\
\text { моделі Чуа [8]) }\end{array}$ & $\begin{array}{c}\mathrm{U}_{\min }=0,18 \mathrm{~B}, \\
\mathrm{U}_{\max }=0,56 \mathrm{~B}, \\
\mathrm{U}_{\mathrm{st}}=0,49 \mathrm{~B}, \\
\mathrm{U}_{\mathrm{st}}=0,25 \mathrm{~B}\end{array}$ & $\begin{array}{l}\mathrm{j}_{\min }=0,010 \\
\mathrm{j}_{\max }=0,042\end{array}$ & 58 \\
\hline Зразок 5 & $\begin{array}{c}\text { Імпульсний } \\
\text { реверсний } \\
\text { (коефіцієнт } \\
\text { заповнення } \mathrm{D}=0,66, \\
\tau=3 c)\end{array}$ & $\begin{array}{l}-0,119 \mathrm{~B} \\
+0,367 \mathrm{~B}\end{array}$ & $\begin{array}{r}-0,0171 \\
+0,0338\end{array}$ & 120 \\
\hline
\end{tabular}

В кожному режимі електроосадження вносилися відповідні часові залежності напруги і вимірювалися відповідні значення сили струму. На Рис.2(а-е) приведено фрагменти часових залежностей напруги та струму в випадку неоднорідних стохастичних режимів. 


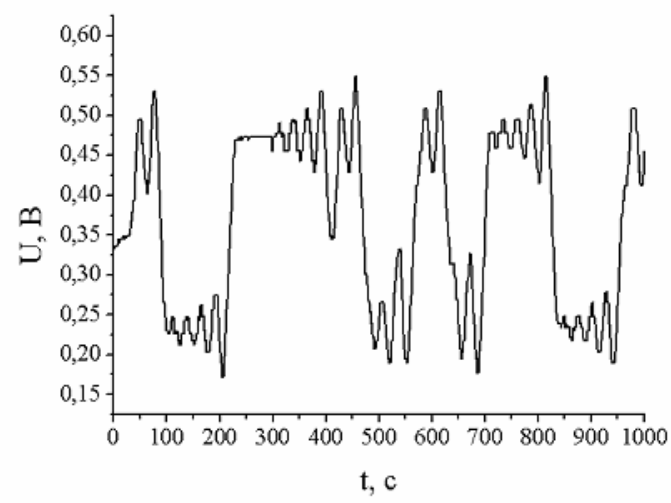

a

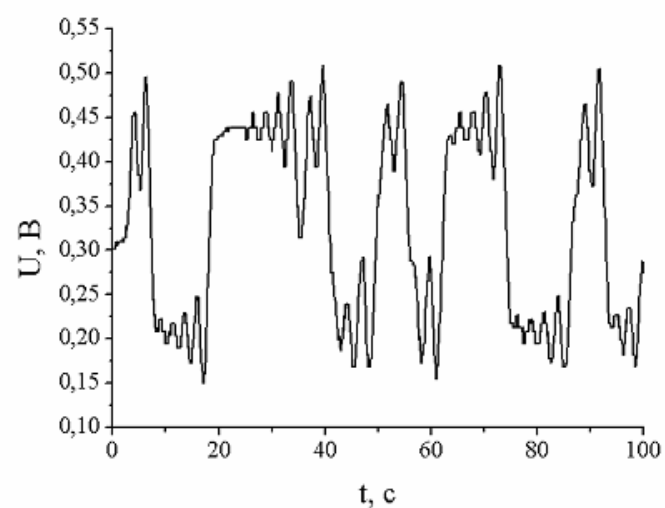

B

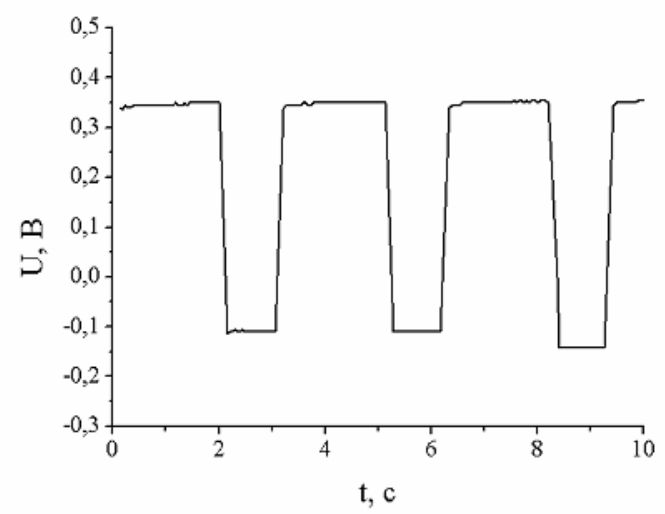

Д

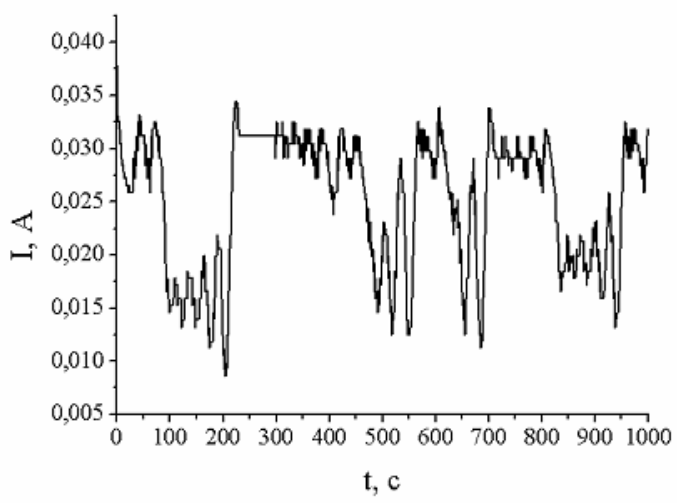

6

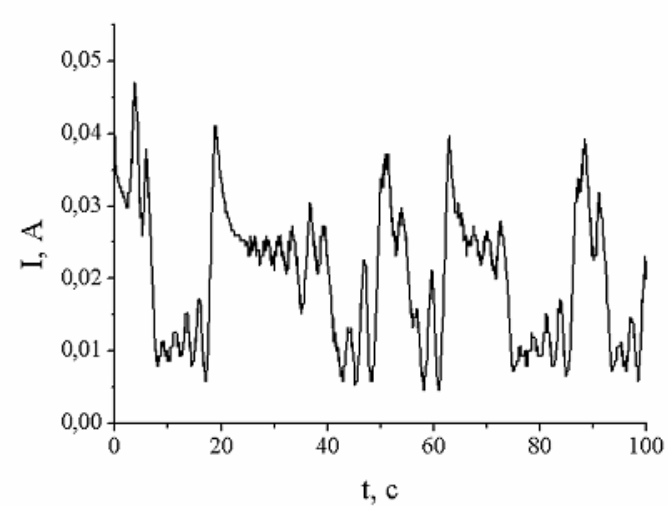

$\Gamma$

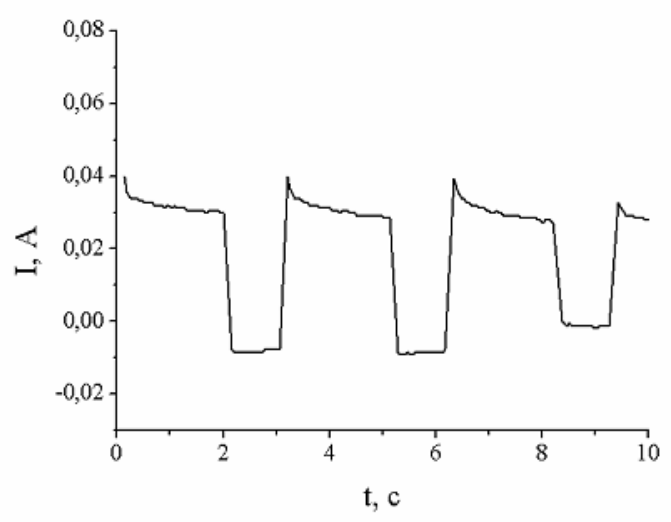

$\mathrm{e}$

Рис.2. Фрагменти часових залежностей напруги та струму в випадку повільного стохастичного (a, б), швидкого стохастичного (в, г) та імпульсного реверсного (д, е) режимів електроосадження.

Fig. 2. Fragments of voltage and current time dependencies in the case of: $a, b-$ slow stochastic; c, d - fast stochastic; e, f - pulsed reverse modes of electrodeposition.

Для реалізації стохастичних режимів електроосадження нами застосовувалися модель генератора Чуа, а саме, модель динамічної системи 3 поведінкою дивного атрактора [5-7]. Застосування цієї моделі дозволяє отримати неперервні переходи напруги електроосадження між двома стаціонарними режимами у випадкові моменти часу. Хід стохастичного процесу розраховувався спочатку методами математичного моделювання, як набір значень випадкової функції в послідовні моменти часу. Розрахований таким чином профіль випадкової функції 
ISSN 2076-5851. Вісник Черкаського університету. Випуск №1. 2018

реалізувався в АПК в двох різних масштабах часу. Два відповідні стохастичні режими (повільний та швидкий) відрізнялися лише шкалою часу, в розглянутому випадку в 500 разів. Повільний стохастичний режим відповідав такій зміні напруги на електродах з часом, коли поляризація електродів відбувалася швидше зміни напруги в часі. В цьому випадку функціональні залежності напруг і сил струму пов'язані визначеною за стаціонарних умов поляризаційною кривою. I, навпаки, в режимі швидкого стохастичного режиму процес нестаціонарного електроосадження відбувався без такого підлаштування сили струму під миттєві значення напруг.

\section{2. Процедура розрахунку уширення піків дифрактограм}

Оцінка розмірів зерен здійснювалася по розширенню дифракційних ліній на дифрактограмах, що отримані від електроосаджених прошарків міді. Ширина піків обернено пропорційна кількості розсіюючих центрів вздовж даного напрямку [11]. Всі ці фактори дають вклади в розширення піків i, відповідно, дозволяють оцінити розміри кристалічних зерен осаду, що розраховується за відомою формулою Селякова - Шеррера [12]:

$$
D=\frac{\lambda}{b \cdot \cos \theta}
$$

де $b$ - напівширина лінії, $\lambda$ - довжина хвилі, $\theta$ - кут дифракції.

Крім того, оскільки, кожен кристаліт осаду може мати блочну структуру, то на підставі результату, отриманого за допомогою виразу (1), можна оцінити розміри областей когерентного розсіювання (ОКР).

\section{3. Дослідження виготовлених зразків}

Отримані зразки були досліджені на рентгенодифрактометрі ДРОН у монохроматичному $\mathrm{FeK}_{\alpha}$-випромінюванні. В якості еталона Сu бралася дифрактограма відпаленого порошку міді (див. Рис. 3a).

Таблиця 2

Відносні інтенсивності дифракційних максимумів електроосаджених прошарків міді

\begin{tabular}{|c|c|c|c|c|c|}
\hline $\begin{array}{l}\text { Кристалографічні індекси сімейств } \\
\text { атомних площин (індекси Міллера) }\end{array}$ & $(111)$ & $(200)$ & $(220)$ & (311) & $(222)$ \\
\hline Зразок 1 & 100 & 34 & 74 & 35 & 10 \\
\hline Зразок 2 & 100 & 30 & 82 & 31 & 8 \\
\hline Зразок 3 & 100 & 36 & 44 & 32 & 11 \\
\hline Зразок 4 & 100 & 34 & 28 & 30 & 11 \\
\hline Зразок 5 & 37 & 9 & 100 & 20 & 6 \\
\hline Еталон (Відпалений порошок міді) & 100 & 43 & 30 & 57 & 21 \\
\hline $\begin{array}{l}\text { Еталон } \\
\text { (Штрих-діаграма бази PDF-2) }\end{array}$ & 100 & 43 & 17 & 16 & 5 \\
\hline
\end{tabular}




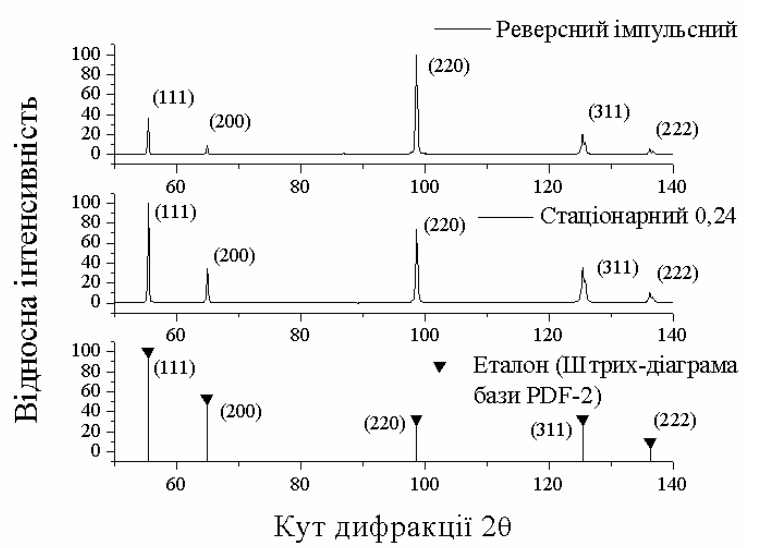

a

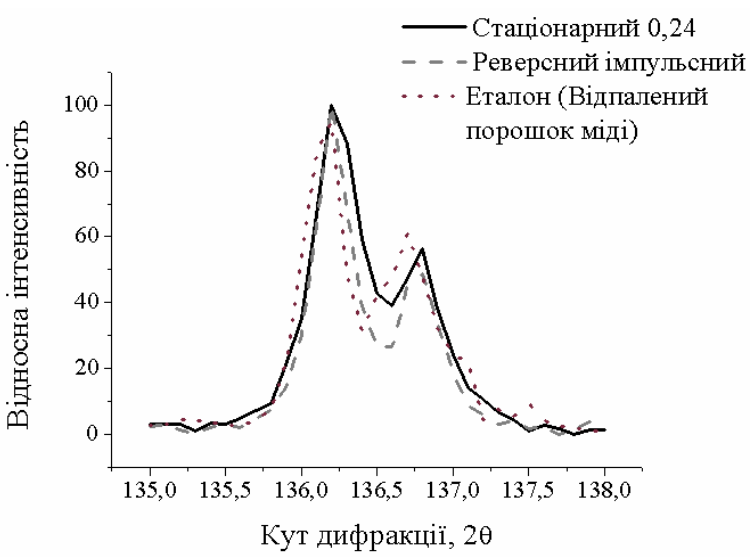

B

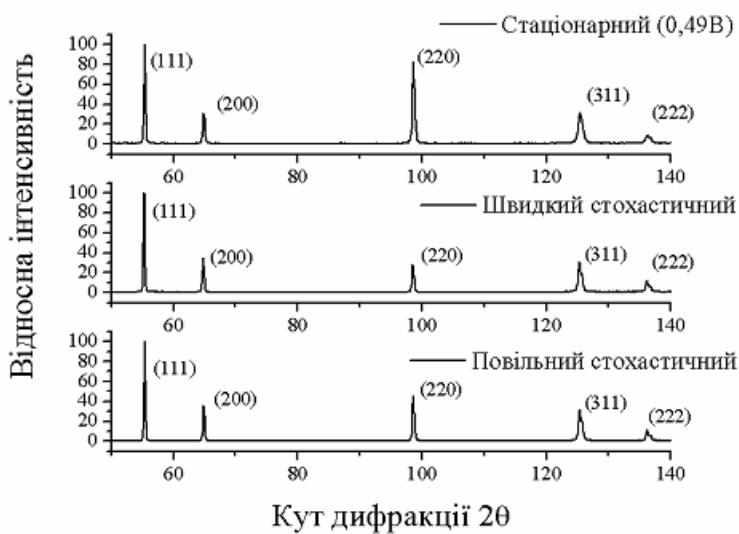

6

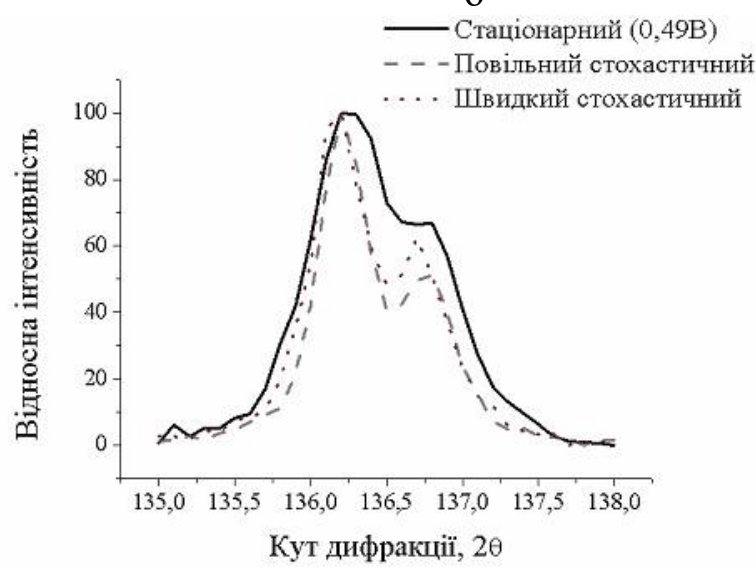

$\Gamma$

Рис. 3. Дифрактограми зразків міді, що електроосаджена у різних режимах за кутів дифракції $50^{\circ}-140^{\circ}\left(\mathrm{a}\right.$, б) та $135^{\circ}-138^{\circ}$ (в, г).

Fig. 3. Diffractograms of the samples with different modes of the copper electrodeposition for diffraction angles: $\mathrm{a}, \mathrm{b}-50^{\circ}-140^{\circ}$; $\mathrm{c}, \mathrm{d}-135^{\circ}-138^{\circ}$.

Якісний розгляд дифрактограм та аналіз даних таблиці 2 показує, що в умовах стохастичного режиму струму електроосадження формується близький до «полікристалічного» осад 3 незначною тенденцією до текстурування вздовж напрямку $<110>$. При цьому, можна констатувати відсутність суттєвого впливу на орієнтаційні структурні характеристики частоти стохастичних коливань. У випадку осадження в стаціонарних умовах (постійний струм), незалежно від потенціалу катоду, текстура (110) осаду стає гострішою, що видно із збільшення відносної інтенсивності дифракційної лінії (220) міді. За імпульсного реверсного режиму електролітичний осад має яскраво виражену аксіальну текстуру вздовж кристалографічного напрямку $<110>$ перпендикулярно до поверхні зразка. Можна припустити, що варіація параметрів (амплітуди і тривалості) імпульсів струму у прямому та зворотному напрямках, буде впливати на ступінь орієнтаційного впорядкування кристалітів міді.

Відомо, що субмікронні розміри кристалітів, мікронапруги та дефектна структура приводять до уширення дифракційних ліній зразка. На Рис.3в наведені нормовані по висоті максимуми (222) електролітичних осадів, що отримані за постійного струму осадження (Зразок 1), за реверсного імпульсного режиму у співставленні 3 еталоном (відпалений порошок міді). По ступеню «розщеплення» К-альфа дублету видно, що більш досконалу структуру має осад, що отриманий в реверсному імпульсному режимі. За постійного струму електроосадження формуються кристали з дефектною структурою.

В Табл. 3 подано інформацію про розраховані мікроструктурні характеристики зразків. При розрахунку розмірів ОКР допускалося, що мікронапруги в Зразках 1-5 відсутні. 
Мікроструктурні характеристики зразків

\begin{tabular}{|c|c|c|c|c|}
\hline Назва & $\begin{array}{c}\text { Кути } \\
\text { дифракційних } \\
\text { піків } 2 \theta, \text { град. }\end{array}$ & $\begin{array}{c}\text { Напівширина } \\
B\end{array}$ & $\begin{array}{c}\text { Фізичне } \\
\text { уширення } \\
\beta \\
\end{array}$ & $\begin{array}{c}\text { Розмір ОКР } D_{H K L}, \\
H \mathcal{M}\end{array}$ \\
\hline Еталон $\mathrm{Cu}$ & 136,19 & 0,22 & & \\
\hline Зразок 1 & 136,22 & 0,36 & 0.182 & 163,3 \\
\hline Зразок 2 & 136,24 & 0,58 & 0.408 & 72,9 \\
\hline Зразок 3 & 136,19 & 0,39 & 0.214 & 139,1 \\
\hline Зразок 4 & 136,15 & 0,37 & 0.15 & 198 \\
\hline Зразок 5 & 136,2 & 0,3 & 0.117 & 253,2 \\
\hline
\end{tabular}

На Рис. 4 приведено гістограми розміру областей когерентного розсіювання Зразків 15.

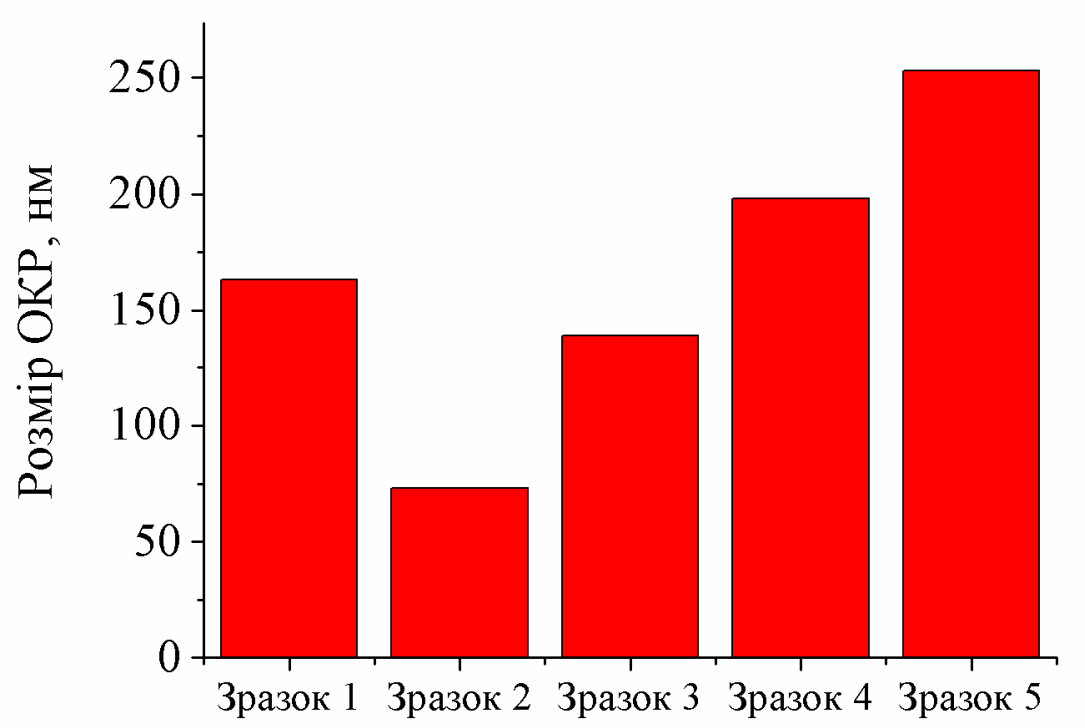

Рис. 4. Гістограма розмірів областей когерентного розсіювання Зразків 1-5.

Fig. 4. Histogram of coherent scattering regions of Samples 1-5.

3 гістограм видно, що розміри ОКР в електроосаджених прошарках, що отримані 3 використанням імпульсного реверсного режиму, більші ніж за інших режимів (Рис. 4). Також встановлено, що після електролітичного осадження міді розмір зерен зменшується, в порівнянні з розмірами зерен в полікристалічній мідній підкладці.

Осад, що отриманий в стохастичних режимах електроосадження, має приблизно такі ж розміри ОКР, що й осад, отриманий в стаціонарному режимі нанесення за напруги $0.44 \mathrm{~B}$, на відміну від інших режимів осадження.

\section{4. Висновки}

В роботі удосконалено технологію отримання прошарків електроосадженої в нестаціонарних режимах міді на мідні підкладки. Для контролю процесу електроосадження використано розроблений автоматизований програмно-апаратний комплекс [8].

Методами рентгенівського дифракційного аналізу досліджено вплив електроосадження в різних режимах на мікроструктуру поверхневих прошарків міді. Проведені розрахунки показали, що уширення дифракційних ліній від зразків, що отримані після електролітичного осадження міді на мідні пластинки, зв'язано зі зменшенням розмірів зерен.

Отримані результати рентгеноструктурного аналізу дозволяють зробити такі висновки: в умовах стохастичного струму формується близький до «полікристалічного» осад 3 незначною 56 
тенденцією до текстурування вздовж напрямку $<110>$. У випадку осадження в стаціонарних умовах (постійний струм), незалежно від потенціалу катоду, текстура (110) осаду стає гострішою, що видно по збільшенню відносної інтенсивності дифракційної лінії (220) міді. За імпульсного реверсного режиму електролітичний осад має яскраво виражену аксіальну текстуру вздовж кристалографічного напрямку <110> перпендикулярно до поверхні зразка.

\section{Список використаної літератури:}

1. Glaiter H. Nanostructured materials: basic concepts and microstructure/ H. Glaiter // Acta Materialia. - 2000. - Vol. 48. - P. 1-29. - DOI:10.1016/S13596454(99)00285-2

2. Беленький М. А. Электроосаждение металлических покрытий: Справочник / М. А. Беленький, А. Ф. Иванов // М.: Металлургия. - 1985. 292 с.

3. Popov K. I. Morphology of electrochemically and chemically deposited metals / K. I. Popov, S. S. Djokic, N. D. Nikolic, V. D. Jovic // Switzerland: Springer. - 2016. 379 p.

4. Медведев А. Импульсная металлизация печатных плат / А. Медведев, П. Семенов // Технологии в электронной промышленности. - 2005. - № 3. - С. 68-70. - Режим доступу: http://echemistry.ru/assets/files/stati/impulsnaya_metallizaciya_pp.pdf

5. Sheshadri B. S. The effect of alternating current on the morphology of electrodeposited copper electrodeposition and surface treatment / B. S. Sheshadri, H. V. Setty // Electrodeposition and Surface Treatment. - 1973. - Vol. 2, № 74. - P. 223-231. - DOI:10.1016/03009416(74)90036-4

6. Килимник А. Б. Электрохимические процессы на постоянном и переменном токе / А. Б. Килимник // Вестник ТГТУ. - 2008. - Т. 14, № 4. - С. 903-916. - Режим доступу: http://vestnik.tstu.ru/rus/t_14/pdf/14_4_015.pdf

7. Стевич 3. Управление импульсным режимом в гальванотехнике / 3. Стевич, М. РайчичВуясинович, 3. Стоилькович // Технология и конструирование в электронной аппаратуре. - 2003. - $\quad$ № 5 . - - C. 51-52. http://dspace.nbuv.gov.ua/bitstream/handle/123456789/70700/15StevichNEW.pdf?sequence $=1$

8. Ніколенко Ю. В. Розробка та застосування апаратно-програмного комплексу у правлінні процесом електролітичного осадження міді в режимі стохастичних коливань / Ю. В. Ніколенко, В. А. Дідук, Я. Д. Король, Ю. О. Ляшенко // Вісник Черкаського університету. Серія «Фізико-математичні науки». - 2016. №1. - С. 27-29. - Режим доступу: http://phys-ejournal.cdu.edu.ua/article/view/1372/1396

9. Морозович В. В. Вплив попереднього оброблення міді на фазо- та пороутворення у твердофазних реакціях міді з циною / В.В.Морозович, А. Р. Гонда, Ю. О. Ляшенко, Я. Д. Король, О. Ю. Ляшенко, Ч. Чергаті, А. М. Гусак // Металофізика та новітні технології. - 2018. - Т. 40, №12. - C. 1649-1673. - DOI:10.15407/mfint.40.12.1649

10. Тютенко В. М. Вплив SMAT обробки на структуру електроосаджених в стацонарному, реверсному та стохастичному режимах прошарків міді / В. М. Тютенко, В. В. Морозович, В. А. Дідук, С. О. Колінько, Ю. О. Ляшенко // Вісник Черкаського університету. Серія «Фізико-математичні науки». - 2017. №1. - С. 63-78. - Режим доступу: http://phys-ejournal.cdu.edu.ua/article/view/2334/2406

11. Русаков А. А. Рентгенография металлов / А. А. Русаков // Московская типография №4, 1976. $-475 \mathrm{c}$.

12. Штольц А. К. Рентгеновский анализ микронапряжений и размера областей когарентного рассеяния в поликристаллических материалах // А. К. Штольц, А. И. Медведев, Л. В. Курбатов // Екатеринбург: ГОУ-ВПО-УГТУ-УПИ. -2005. - С. 1-23. - Режим доступу: https://docplayer.ru/47621595-Rentgenovskiy-analiz-mikronapryazheniy-i-razmeraoblastey-kogerentnogo-rasseyaniya-v-polikristallicheskih-materialah.html 


\section{References:}

1. Glaiter H. (2000). Nanostructured materials: basic concepts and microstructure. Acta Materialia, 48, 1-29. - DOI:10.1016/S1359-6454(99)00285-2

2. Belenkyi M. A., Ivanov A. F. (1985). Electrodeposition of metal coatings: Handbook. Moscow: Metallurgy (in Rus).

3. Popov K. I. Djokic S. S., Nikolic N. D., Jovic V. D. (2016). Morphology of electrochemically and chemically deposited metals. Switzerland: Springer.

4. Medvedev A A., Semenov S. (2005). Pulsed metallization of printed circuit boards. Tekhnolohyy $V$ Elektronnoi Promyshlennosty (Technology in the Electronic Industry), 3, 68-70. - Retrieved from http://echemistry.ru/assets/files/stati/impulsnaya_metallizaciya pp.pdf

5. Sheshadri B. S., Setty H. V. (1973). The effect of alternating current on the morphology of electrodeposited copper electrodeposition and surface treatment. Electrodeposition and Surface Treatment, 2(74), 223-231. - DOI:10.1016/0300-9416(74)90036-4

6. Kilimnik A. B. (2008). Electrochemical processes on direct and alternating current. Vestnik TGTU (Bulletin of TSTU), 14(4), 903-916. - Retrieved from http://vestnik.tstu.ru/rus/t_14/pdf/14_4_015.pdf

7. Stevich Z., Raychich-Vuyasinovich M., Stoilkovich Z. (2003). Control of impulse mode in electroplating. Tekhnologiya $i$ konstruirovaniye $v$ elektronnoy apparature (Technology and design in electronic equipment), 5, 51-52. - Retrieved from http://dspace.nbuv.gov.ua/bitstream/handle/123456789/70700/15-

StevichNEW.pdf?sequence $=1$

8. Nikolenko Yu. V., Diduk V. A., Korol Ya. K., Lyashenko Y. O. (2016). Development and application of the hardware and software complex in the board by the process of electrolytic deposition of copper in the mode of stochastic oscillations. Visnyk Cherkaskoho Universytetu. Seriia «Fizyko-Matematychni Nauky» (Bulletin of Cherkasy University. Series "Physics and Mathematics"), 1, 27-29. - $\quad$ Retrieved from http://physejournal.cdu.edu.ua/article/view/1372/1396

9. Morozovych V. V., Honda A. R., Lyashenko Yu. O., Korol Ya. D., Liashenko O. Yu., Cserháti C., and Gusak A. M. (2018) Influence of Copper Pretreatment on the Phase and Pore Formations in the Solid Phase Reactions of Copper with Tin. Metallofiz. Noveishie Tekhnol., 40(12): 1649-1673. - DOI:10.15407/mfint.40.12.1649

10. Tiutenko, V. M., Morozovych, V. V., Diduk, V. A., Kolinko, S., \& Lyashenko, Y. O. (2018). The influence of SMAT processing on microstructure of copper films electroplated in steadystate, reversed impulse and stochastic regimes. Cherkasy University Bulletin: Physical and Mathematical Sciences, 1, 63-78. - Retrieved from http://physejournal.cdu.edu.ua/article/view/2334/2406.

11. Rusakov A. A. (1971). X-ray of metals. Moscow: Moscow printing house (in Rus).

12. Shtol'ts A. K., Medvedev A. I., Kurbatov L. V. (2005). X-ray analysis of microstresses and the size of the regions of coherent scattering in polycrystalline materials. Yekaterinburg: $G O U-$ VPO-UTTU-UPI (Yekaterinburg: GO-WEI USTU), 16-17. - Retrieved from https://docplayer.ru/47621595-Rentgenovskiy-analiz-mikronapryazheniy-i-razmera-oblasteykogerentnogo-rasseyaniya-v-polikristallicheskih-materialah.html

\section{V. Morozovych}

Post-graduate student of the Department of Physics, The Bohdan Khmelnytsky National University of Cherkasy, Cherkasy, Ukraine, vladmorozua@gmail.com 
Ya. D. Korol

Candidate of physical and mathematical sciences, associate professor,

Director of the Educational and Scientific Center for Physical and Chemical Research,

The Bohdan Khmelnytsky National University of Cherkasy, Cherkasy, Ukraine, yaking@ukr.net

\section{Yu. O. Lyashenko}

Doctor of physical and mathematical sciences, Associate Professor,

Director of Educational and Scientific Institute of Information and Educational Technologies,

The Bohdan Khmelnytsky National University of Cherkasy, Cherkasy, Ukraine,

urico@ukr.net

\section{STRUCTURAL STATE OF ELECTRODEPOSITED COPPER LAYERS}

Summary. The aim of this work is a systematic application of hardware software for the production of cooper electrodeposited in stationary, reverse pulse and stochastic modes. Investigation of the influence of different modes of electrodeposition on the microstructure of the surface layers of copper by $x$-ray diffraction analysis is conducted.

The microstructure of copper layers obtained by electrodeposition in stationary, reverse pulse and stochastic modes on copper substrates was studied by X-ray diffraction analysis. The significant influence of the current form on the texture of the deposited copper layers is established. The size of coherent scattering regions in layers obtained under different current regimes is determined by analyzing the broadening of diffraction lines.

In work the technology of reception of layers of electrodeposition in stationary, reverse pulse and stochastic modes of copper on copper substrates is fulfilled. The control of electrodeposition process, an automated software and hardware system were developed.

The influence of electrodeposition in different modes on the microstructure of the surface layers of copper was studied by X-ray diffraction analysis. The calculations showed that the broadening of the diffraction lines from the samples obtained after electrolytic deposition of copper on copper plates is associated with a decrease in grain size.

The obtained results of structural analysis allow us to draw the following conclusions: under the conditions of stochastic current, a precipitate close to "polycrystal" is formed with a slight tendency to texturing along the direction $<110>$. In the case of stationary deposition (direct current), regardless of the cathode potential, the sediment texture (110) becomes sharper, as can be seen from the increase in the relative intensity of the copper diffraction line (220). Due to the pulsed reverse mode, the electrolytic precipitate has a pronounced axial texture along the crystallographic direction $<110>$ perpendicular to the surface of the sample.

The size of coherent scattering regions in electrodeposited layers obtained using the pulsed reverse mode is larger than in other modes. It was also found that after electrolytic deposition of copper grain size decreases compared to the grain size in the polycrystalline copper substrate.

Keywords: electrodeposition, x-ray diffraction analysis, copper, region of coherent scattering, diffraction pattern.

Одержано редакиією 18.03 .2018

Прийнято до друку 18.12.2018 